\title{
Antibacterial Activity of 3-Methylcyclopentanone Derivatives in Relation to Methylenomycins
}

\author{
Kennosuke TONARI ${ }^{* 1}$ and Keiichiro SAMESHIMA*2 \\ *1 Course of Industrial Chemistry, Kinki Polytechnic College \\ (1778 Inaba-cho Kishiwada, Osaka 596-0103) \\ *2 Department of Computer Chemistry System, Fujitsu Limited \\ (9-3 Nakase Mihama, Chiba-ken 261-8588)
}

\begin{abstract}
Methylcyclopentanone derivatives were synthesized for examination of antibacterial activity, and it was evaluated by molecular orbital calculation.

This parameter at minimum inhibitory concentration(MIC) was found closely correlated with absolute electronegativity $(\chi)$ derived from the highest occupied molecular orbital (HOMO) and the lowest unoccupied molecular orbital(LUMO). The values of $\Delta \mathrm{N}$ and $\Delta \mathrm{E}$ calculated from $\chi$ and absolute hardness $(\eta)$ of 3-methylcyclopentanones and amino acids also showed good correlation with MIC. In relation to methylenomycins, cyclopentanone antibiotics, antibacterial activity was investigated by comparing the $\chi, \Delta \mathrm{N}$ and $\Delta \mathrm{E}$.

2,3-Epoxy-3-methyl-5-methylenecyclopentanone 4 whose antibacterial activity was the strongest, may possibly have potential as a cyclopentanone antibiotic based on $\chi, \Delta \mathrm{N}$ and $\Delta \mathrm{E}$ data.

Key words : antibacterial activity, 3-methylcyclopentanones, methylenomycins, absolute electronegativity $(\chi)$, quantity of electron $\operatorname{transfer}(\Delta \mathrm{N})$, stabilization energy $(\Delta \mathrm{E})$
\end{abstract}

\section{Introduction}

Methylenomycin A and B were firstly isolated from a strain of Streptmyces violaceruber and claimed the structure for 4-carboxy-2,3-dimethyl2,3-epoxy-5-methylenecyclopentanone and 2,3dimethyl-5-methylene-2-cyclopentenone, respectively ${ }^{1-a}$. Those compounds known as methylenomycins were medicinally important cyclopentanone antibiotics and much attention was devoted on the synthesis of those $\mathrm{e}^{2) \sim 7)}$.

We were interested in the compounds of 3methyl-5-methylene-2-cyclopentenone 3 and 2,3epoxy-3-methyl-5-methylenecyclopentanone 4 which are structually similar to methylenomycin A and B and simplicity in structures promted us to synthesize both as well as their related compounds. And the evaluation of antibacterial activities of those was a focus of interest.

Synthetic works for 3-methyl-2-cyclopentenone 1, 2,3-epoxy-3-methylcyclopentanone 2 as well as

Corresponding author : kennosuke TONARI
3 and 4 were carried out starting from 2,5hexanedione(acetonyl acetone). The epoxydation of $\mathbf{1}$ and exomethylenation of $\mathbf{1}$ and 2 were conducted by usual manner as shown in Fig. 2 . On the reaction with chloride ion, both 2 and 4 were easily converted to 2-chloro-3-methyl-2-cyclopentenone 5 and 2-chloro-3-methyl-5-methylene2-cyclopentenone 6 , respectively.

For the evaluation of biological activity, absolute hardness $(\eta$ : originated from the principle of hard and soft acids and bases) and absolute electronegativity $(\chi)$ which calculated from HOMO, LUMO ${ }^{8)}$ of 3-methylcyclopentanones were discussed with a consideration of a lipohydrophilic character of these. It is generally understood that the biological activity (or antibacterial activity) has been proposed to involve binding of the substrate with amino acid residue in enzyme or protein. Especially, the amino acid residues in active center in enzyme are generally composed of $-\mathrm{SH},-\mathrm{OH}$ or $-\mathrm{NH}_{2}(=\mathrm{NH})$ groups which originate from cysteine, serine or lysine(histidine), respectively" ${ }^{9}$. Binding these amino acid 

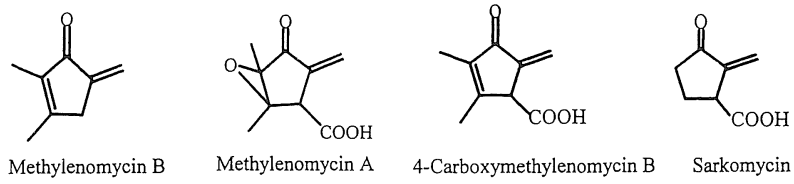

Fig. 1 Methylenomycin (A \& B) and Related Compounds.

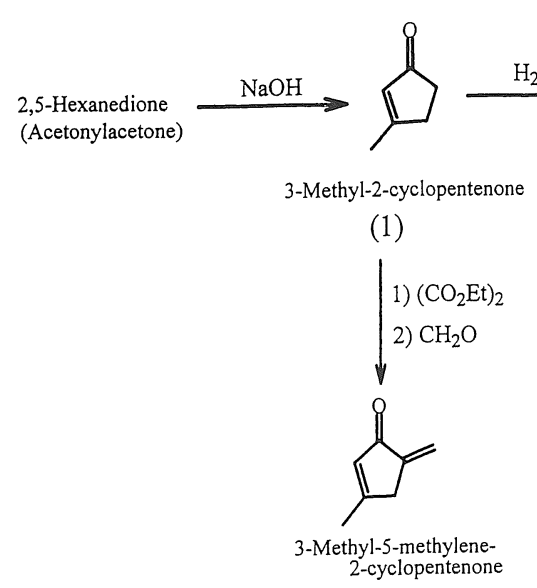

(3)

Fig. 2 Synthetic Routes for 3-Methylcyclopentanones.

residues with substrate means an inactivation of enzyme and this develops to the antibacterial activity. Studying the reaction of these amino acids with 3-methylcyclopentanones seemed an important aspect for the discussion of the antibacterial activity. Amino acids like these have electron donating groups of $-\mathrm{SH},-\mathrm{OH}$ or $-\mathrm{NH}_{2}(=\mathrm{NH})$, while 3-methylcyclopentanones containig the enone or epoxy functional groups in the molecule would serve as electron accepting groups. Under these compounds of both, the reaction of Michael type would be expected to occur as seen in the literature ${ }^{10)}$.

For further discussion of antibacterial activity, a molecular interpretation of binding affinity of amino acid and 3-methylcyclopentanones was incorporated with the considerations of the quantity of electron transfer $(\Delta \mathrm{N})$ from amino acid to 3-methylcyclopentanones and the stabilization enegy $(\Delta \mathrm{E})$ for binding both ${ }^{8)}$. The $\chi, \Delta \mathrm{N}$ and $\Delta \mathrm{E}$ of methylenomycins were also compared with those of the compounds $(1 \sim 6)$, and the relationship between the structure and antibacterial activity of those related compounds was discussed.

\section{Experimental}

\section{$2 \cdot 1$ Synthesis}

GC-MS spectra were taken on a Hewlett Packard 5890 Q-pole spectrometer at $70 \mathrm{eV}$ and major peaks were indicated as $\mathrm{m} / \mathrm{z}$. (methylsilicone gum $10 \mathrm{~m}, 80-150^{\circ} \mathrm{C} / 5^{\circ} \mathrm{C}$ rating, flow rate $\mathrm{He} 45$ $\mathrm{ml} / \mathrm{min}$.) NMR spectra were recorded on a JEOL JNM-MY 60 and IR spectra were obtained on a Shimadzu IR 400 spectrometer, respectively.

\section{3-Methyl-2-cyclopentenone(1)}

This compound was easily prepared from the treatment of acetonylacetone in dilute alkaline solution $^{11)}$. Also, this was supplied by Tokyo Kasei Kogyo Co., Ltd. bp. $90 \sim 95^{\circ} \mathrm{C} / 17 \mathrm{~mm} \mathrm{MS} \mathrm{m/z}$ (rel.int.) : 96( $\left.\mathrm{M}^{+}, 100\right)$, 81(M-15, 36), 67(39), 53 (26) IR $\nu_{\max }($ film $) \mathrm{cm}^{-1}: 3450,2850,1670,1590$, $1400,1250,1150,930,805{ }^{1} \mathrm{H}-\mathrm{NMR}\left(\mathrm{CCl}_{4}\right) \delta: 2.08$ $\left(3 \mathrm{H}, \mathrm{s}, \mathrm{CH}_{3}\right), 2.27-2.57\left(4 \mathrm{H}, \mathrm{m}, 2 \mathrm{xCH}_{2}\right), 5.75(\mathrm{H}$, $\mathrm{s}, \mathrm{C}=\mathrm{CH}$ ).

\section{2,3-Epoxy-3-methylcyclopentanone(2)}

$9.6 \mathrm{~g}$ of 1 in $60 \mathrm{~mL}$ of $\mathrm{MeOH}$ was converted to 2 with $15 \mathrm{~mL}$ of $30 \% \mathrm{H}_{2} \mathrm{O}_{2}$ in usual manner ${ }^{12)}$. bp. 65 $\sim 70^{\circ} \mathrm{C} / 15 \mathrm{~mm} \mathrm{MS} \mathrm{m} / \mathrm{z}$ (rel.int. ) : $112\left(\mathrm{M}^{+}, 100\right), 97$ (M-15,8.6), 83(12.9), 69(39.8), 55(57) IR $\nu_{\max }$ 
(film) $\mathrm{cm}^{-1}:$ 3450, 2950, 1740, 1410, 1260, 1220, $1060,840,800{ }^{1} \mathrm{H}-\mathrm{NMR}\left(\mathrm{CCl}_{4}\right) \delta: 1.51(3 \mathrm{H}, \mathrm{s}$, $\left.\mathrm{CH}_{3}\right), 2.0-2.14\left(4 \mathrm{H}, \mathrm{m}, 2 \mathrm{xCH} \mathrm{CH}_{2}\right), 2.96(\mathrm{H}, \mathrm{s}$, epoxy$\mathrm{H})$.

\section{3-Methyl-5-methylene-2-cyclopentenone(3)}

To a stirred solution of NaOEt $(0.04 \mathrm{~mol})$ in 30 $\mathrm{mL}$ of $\mathrm{EtOH}$ was added $2.9 \mathrm{~g}$ of $\mathbf{1}$ and $5.8 \mathrm{~g}$ of ethyl oxalate and the mixture was stirred for $1 \mathrm{hr}$ at room temperature. The resulted sodioderivative of (1)-oxalate was poured onto THF and treated with $9 \mathrm{~mL}$ of $37 \%$ formalin. After extraction with ether, extracts was washed with $10 \% \mathrm{KHCO}_{3}$ and dried over $\mathrm{Na}_{2} \mathrm{SO}_{4}$. Usual work up gave $2.8 \mathrm{~g}$ of 3 as a light brown oil. MS m/z (rel.int.) : 108 $\left(\mathrm{M}^{+}, 100\right), 93$ (M-15,2.2), 79 (76), 65 (8.6), 53 (5.4) IR $\nu_{\max }($ film $) \mathrm{cm}^{-1}: 3400,2900,1740,1680,1640$, $1600,1410,1380,1260,1180,1100,1000,920,850$ ${ }^{1} \mathrm{H}-\mathrm{NMR}\left(\mathrm{CCl}_{4}\right) \delta: 2.1\left(3 \mathrm{H}, \mathrm{s}, \mathrm{CH}_{3}\right), 3.16(2 \mathrm{H}, \mathrm{m}$, $\left.\mathrm{CH}_{2}\right), 5.80(\mathrm{H}, \mathrm{s},=\mathrm{CH}$ at s-trans $\mathrm{C}=\mathrm{O}), 5.9(\mathrm{H}, \mathrm{s}$, $=\mathrm{CH}$ at s-cis $\mathrm{C}=\mathrm{O}), 6.05(\mathrm{H}, \mathrm{s},=\mathrm{CH}$ at s-cis $\mathrm{C}=$ O)

\section{2,3-Epoxy-3-methyl-5-methylenecyclopenta- none(4)}

To a stirred suspension of $\mathrm{NaH}(1.7 \mathrm{~g})$ in $30 \mathrm{~mL}$ of ether was added $4.5 \mathrm{~g}$ of 2 and $7.3 \mathrm{~g}$ of ethyl oxalate, and then a few drops of $\mathrm{EtOH}$ was added to initiate the reaction. After stirring for $3 \mathrm{hrs}$ at room temperature, the resulted brown colored mixture was poured into water and the sodioderivative of (2)-oxalate was extracted with water for several times. To the water extracts was added 12 $\mathrm{mL}$ of $37 \%$ formalin and the mixture was stirred for $1 \mathrm{hr}$ at room temperature. After extraction with ether, extracts was concentrated in vacuo and subjected to a silicagel colum chromatography(ether : hexane $=1: 1$ ) for purification. 300 $\mathrm{mg}$ of 4 was isolated as a colorless oil. MS $\mathrm{m} / \mathrm{z}$ (rel.int.) : $124\left(\mathrm{M}^{+}, 18\right), 95$ (100), 82 (11), 67 (84), 54 (23) IR $\nu_{\max }\left(\right.$ film) $\mathrm{cm}^{-1}: 3300,2905,2915$, $1760,1730,1690,1640,1440,1420,1400,1370$, $1180,1160,1100,1030,810{ }^{1} \mathrm{H}-\mathrm{NMR}\left(\mathrm{CCl}_{4}\right) \delta:$ $1.59\left(3 \mathrm{H}, \mathrm{s}, \mathrm{CH}_{3}\right), 2.68-2.84\left(2 \mathrm{H}, \mathrm{m}, \mathrm{CH}_{2}\right), 3.31(\mathrm{H}$, $\mathrm{s}$, epoxy-H), $5.35(\mathrm{H}, \mathrm{s},=\mathrm{CH}$ at s-cis $\mathrm{C}=\mathrm{O}), 6.05$ $(\mathrm{H}, \mathrm{s},=\mathrm{CH}$ at s-cis $\mathrm{C}=\mathrm{O})$

\section{2-Chloro-3-methyl-2-cyclopentenone(5)}

$30 \mathrm{mg}$ of 2 in $1 \mathrm{~mL}$ of acetone was mixed with 5 $\mathrm{mL}$ of $1 \%$ saline at room temperature and left overnight. Extraction with ether gave $\mathbf{5}$ as a colorless oil. $\mathrm{MS} \mathrm{m} / \mathrm{z}$ (rel.int.) : $132\left(\mathrm{M}^{+}+2,32.6\right)$, $130\left(\mathrm{M}^{+}, 100\right), 117$ (4.3), 115 (15.2), 104 (9.8), 102
(30.4), 95 (19.6), 89 (3.2), 87 (10.8), 67 (63), 65 (16.3) IR $\nu_{\max }($ film $) \mathrm{cm}^{-1}: 3460,2900,1650,1580$, $1410,1240,1140,940,810^{1} \mathrm{H}-\mathrm{NMR}\left(\mathrm{CCl}_{4}\right) \delta: 2.12$ (3 $\left.\mathrm{H}, \mathrm{s}, \mathrm{CH}_{3}\right), 2.30-2.60\left(4 \mathrm{H}, \mathrm{m}, 2 \mathrm{xCH}_{2}\right)$

2-Chloro-3-methyl-5-methylene-2-cyclopentenone(6)

$20 \mathrm{mg}$ of 4 in $1 \mathrm{~mL}$ of acetone solution was mixed with $5 \mathrm{~mL}$ of $1 \%$ saline as above and the same treatment afforded 6 as a colorless oil.

MS m/z(rel.int.) : $144\left(\mathrm{M}^{+}+2,33.0\right), 142\left(\mathrm{M}^{+}\right.$, 100), 129 (1.0), 127 (3.2), $116(9.6), 114$ (34.4), 107 (22.6), 101 (2.2), 99 (9.7), 79 (90.3), 77 (60.2), 75 (6.5), 73 (8.6) IR $\nu_{\max }($ film $) \mathrm{cm}^{-1}: 3350,2920$, $1720,1650,1630,1590,1400,1370,1230,1160$, 1080, 950, 900, $860{ }^{1} \mathrm{H}-\mathrm{NMR}\left(\mathrm{CCl}_{4}\right) \quad \delta: 2.15$ (3 $\left.\mathrm{H}, \mathrm{s}, \mathrm{CH}_{3}\right), 3.22\left(2 \mathrm{H}, \mathrm{m}, \mathrm{CH}_{2}\right), 5.30(\mathrm{H}, \mathrm{s},=\mathrm{CH}$ at scis $\mathrm{C}=\mathrm{O}), 6.0(\mathrm{H}, \mathrm{s},=\mathrm{CH}$ at $\mathrm{s}$-cis $\mathrm{C}=\mathrm{O})$

$2 \cdot 2$ Measurements of Antibacterial Activity

Paper disk method was conveniently used for the comparison of the tested compounds and a measurment of MIC of those was performed by the previous method ${ }^{13)}$. The result was shown in Table 1.

2.3 Metabolite Study of the Compounds

To learn a metabolite of the tested compounds, GC-MS study was incorporated. To an each $3 \mathrm{~mL}$ of Bacillus subtilis IFO 3009 suspended in isotonic sodium chloride solution and the same volume of without bacteria solution, was added the $100 \mu \mathrm{L}$ of 3 -methylcyclopentanones in $1 \%$ acetone solution and $2 \mu \mathrm{L}$ of ethylbenzene as an internal standard, and whole was incubated at $36^{\circ} \mathrm{C}$ for each incubation hour. After each incubation hour, $2 \mathrm{~mL}$ of ether was added for the extraction of the tested compounds and the metabolites, and the extracts were concentrated in vacuo. To the residue was added a $50 \mu \mathrm{L}$ of acetone and $5 \mu \mathrm{L}$ of which was injected for GC-MS analysis.

\subsection{Computer Calculation Method}

Throughout this paper, semiempilical quantum chemical calculation has been performed by using MOPAC 97 in winMOPAC(v.2) program package released by Fujitsu Co., Ltd. ${ }^{14)}$. All the structures in 3-methylcyclopentanones and lysine, cysteine, serine and histidine were optimized with AM 1 Hamiltonian. The orbital energies of HOMO and LUMO, absolute hardness $(\eta)$ and absolute electronegativity $(\chi)$ of 3-methylcyclopentanones and amino acids were calculated from following equations and the results were listed in Table 2. 
Table 1 Antibacterial Activities of 3-Methylcyclopentanone Derivatives.

\begin{tabular}{lc|c|c|c|c}
\hline & & \multicolumn{2}{|c|}{ Inhibition zones* } & \multicolumn{2}{c}{ MIC $^{* *}(\mu \mathrm{g} / \mathrm{mL})$} \\
\cline { 3 - 6 } & & $\begin{array}{c}\text { B. subtilis } \\
\text { IF03009 }\end{array}$ & $\begin{array}{c}\text { E. coli } \\
\text { IF03301 }\end{array}$ & $\begin{array}{c}\text { B. subtilis } \\
\text { IF03009 }\end{array}$ & $\begin{array}{c}\text { E. coli } \\
\text { IF03301 }\end{array}$ \\
\hline 3-Methyl-2-cyclopentenone & $(1)$ & + & + & 410 & 420 \\
2,3-Epoxy-3-methylcyclopentanone & $(2)$ & \pm & + & 520 & 500 \\
3-Methyl-5-methylene-2-cyclopentenone & $(3)$ & ++ & ++ & 200 & 180 \\
2,3-Epoxy-3-methyl-5-methylenecyclopentanone & $(4)$ & +++ & +++ & 70 & 40 \\
2-Chloro-3-methyl-2-cyclopentenone & $(5)$ & \pm & + & 420 & 420 \\
2-Chloro-3-methyl-5-methylene-2-cyclopentenone & $(6)$ & + & + & 340 & 400 \\
Sorbic acid & & \pm & + & 500 & 500 \\
\hline
\end{tabular}

$* 30 \mu \mathrm{L}$ of $1 \%$ acetone solution of the tested compounds were absorbed in paper discs (8mm). After drying brifly, these were subjected for the test. zone size: $+++30-40 \mathrm{~mm},++20-29 \mathrm{~mm},+10-$ $19 \mathrm{~mm}, \pm 8-9 \mathrm{~mm}$

$* * 10 \mu \mathrm{g} / \mathrm{mL}$ gradations in concentrations were used. Figures showed distinct no growth concentrations.

Table 2 Calculated Absolute Hardness $(\eta)$, Electronegativity $(\chi)$ of 3-Methylcyclopentanones and Some Amino Acids (eV).

\begin{tabular}{lr|rrrr}
\hline & & HOMO & LUMO & $\chi$ & $\eta$ \\
\hline 3-Methyl-2-cyclopentenone & $(1)$ & -10.071 & -0.047 & 5.059 & 5.012 \\
2,3-Epoxy-3-methylcyclopentanone & $(2)$ & -10.449 & 0.484 & 4.983 & 5.467 \\
3-Methyl-5-methylene-2-cyclopentenone & $(3)$ & -10.026 & -0.259 & 5.143 & 4.884 \\
2,3-Epoxy-3-methyl-5-methylenecyclopentanone & $(4)$ & -10.460 & -0.194 & 5.327 & 5.133 \\
2-Chloro-3-methyl-2-cyclopentenone & $(5)$ & -9.736 & -0.312 & 5.024 & 4.712 \\
2-Chloro-3-methyl-5-methylene-2-cyclopentenone & $(6)$ & -9.720 & -0.487 & 5.104 & 4.617 \\
Lysine & & -9.940 & 1.175 & 4.383 & 5.558 \\
Cysteine & & -9.223 & 0.520 & 4.352 & 4.872 \\
Serine & & -10.581 & 0.912 & 4.835 & 5.747 \\
Histidine & & -9.191 & 0.556 & 4.318 & 4.874 \\
\hline
\end{tabular}

* At the AM1 level

$\eta=1 / 2(\partial \mu / \partial \mathrm{N})_{\nu}=1 / 2\left(\partial^{2} \mathrm{E} / \partial \mathrm{N}^{2}\right)_{\nu}=1 / 2(\mathrm{~A}-\mathrm{I})$

$\chi=-\mu=(\partial \mathrm{E} / \partial \mathrm{N})_{\nu}=-1 / 2(\mathrm{I}+\mathrm{A})$

$\eta=1 / 2\left(\varepsilon_{\text {LUм0 }}-\varepsilon_{\text {номо }}\right), \quad \chi=-1 / 2\left(\varepsilon_{\text {номо }}+\varepsilon_{\text {LUMO }}\right)$

where $\nu, E$ and $\mu$ are the external potential, the energy and the chemical potential of the ground state with $\mathrm{N}$ electrons. I and $\mathrm{A}$ are ionization energy and electron affinity in $\mathrm{eV}$, respectively.

The quantity of electron transfer $(\Delta \mathrm{N})$ and stabilization energy $(\Delta \mathrm{E})$ for the reaction of 3methylcyclopentanones with amino acids, were calculated using following equations ${ }^{8}$.

$$
\begin{aligned}
& \Delta \mathrm{N}=\left(\chi_{\mathrm{B}}-\chi_{\mathrm{A}}\right) / 2\left(\eta_{\mathrm{A}}+\eta_{\mathrm{B}}\right) \\
& \Delta \mathrm{E}=-\left(\chi_{\mathrm{B}}-\chi_{\mathrm{A}}\right)^{2} / 4\left(\eta_{\mathrm{A}}+\eta_{\mathrm{B}}\right)
\end{aligned}
$$

where $\mathrm{A}$ and $\mathrm{B}$ represent the $\chi$ and $\eta$ of amino acids and 3-methylcyclopentanones, respectively.

\section{Results and Discussion}

GC-MS study revealed the metabolites of the 3methylcyclopentanones. The peaks of the compounds ( 1 and 3 ) in GC showed no remarkable change at elapsed incubation times, but on the compounds ( 2 and 4 ), appeared new peaks at 1 hour elapsed incubation and gradually increased with a decrease of 2 and 4 . These new peaks were identified as 2-chloro-3-methylcyclopentenones, i.e.(5 and 6). These compounds were non-enzymatically formed products, which were confirmed by the experiment without bacteria incubation and the reaction with saline and the compounds $(2$ and 4). No conversion was occured without chloride ion on both compounds. There was a literature dealing non-enzymatical formation of chlorinated 
products in biosynthesis of epoxydon and related compounds ${ }^{15)}$. Also, it was confirmed that the $\mathrm{Cl}^{-}$ and the $\mathrm{C} 2$ at epoxy ring of the compounds $(2$ and 4) were found to react by the reaction step method in computer calculation and graphically shown LUMO of $\mathrm{C} 2$ at epoxy ring of the compounds(2 and 4) were big enough to react with HOMO of $\mathrm{Cl}^{-}$. Therefore, the $\mathrm{Cl}^{-}$may attack the epoxy ring at $\mathrm{C} 2$ of the compounds and then ring opening, followed by dehydration affords the compounds ( 5 and 6), respectively.

To discuss the antibacterial activity of 3-methylcyclopentanones, the relationships between the values of $\chi$ and $\eta$ as well as MIC of these were investigated, and found that the $\chi$ of 3-methylcyclopentanones correlated well with MIC in logarithum as shown in Fig. 3. ( $\mathrm{r}=-0.981$ for B.subtilis and -0.960 for E.coli) This means the compounds of higher $\chi$ show stronger antibacterial activity than those of lower. But the relationship between $\eta$ of 3-methylcyclopentanones and MIC in logarithum did not show clear correlation. $(\mathrm{r}=-$ 0.034 for B.subtilis and 0.065 for E.coli).

It is likely that the antibacterial activity of 3methylcyclopentanones is controlled by absolute electronegativity more than absolute hardness.

The lipo-hydrophilic character of a molecule has been well stated and is useful method for the evaluation of biological activity ${ }^{16 \sim 18}$.

$\log \mathrm{P}(\log$ arithum of partition coefficient $)$ of the compounds $(\mathbf{1} \sim \mathbf{6})$ and 3-methylcyclopentanone were calculated using the Tables of physicochemical constants in aliphatic compounds ${ }^{17)}$ and the substituent constants $(\pi)$ of the compounds $(1 \sim 6)$ were calculated from $\log \mathrm{P}$ of each compound - $\log$ $\mathrm{P}$ of 3-methylcyclopentanone. Using the substit-

\section{(a) B.subtilis}

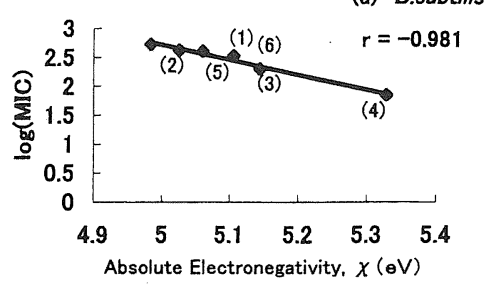

uent constants, regression analysis was made on the effect of substituents in antibacterial activity of 3-methylcyclopentanones on B.subtilis and E.coli.

However, the low correlation coefficient was found between the observed and the calculated MIC in molar concentration expressed as $\log (1 / \mathrm{C})$. (i.e. $\log (1 / \mathrm{C})=2.481+0.0467 \pi^{2}-0.1427 \pi, \mathrm{r}=$ 0.198 for B.subtilis and $\log (1 / \mathrm{C})=2.488-0.0944 \pi^{2}$ $-0.3658 \pi, \mathrm{r}=0.285$ for E.coli) It seems that the molecules having functional groups restricted within benzene ring, for instance, would afford a good correlation between the observed and the calculated biological activity ${ }^{16}$. But in 3-methylcyclopentanones, variety in functional groups in cyclopentanone rings, it is hardly expect to have a good correlationship. The correlation coefficient between the $\chi$ and $\log \mathrm{P}$ also showed low value. (r $=-0.207)$.

We incorporated $\Delta \mathrm{N}$ and $\Delta \mathrm{E}$ for further interpretation between 3-methylcyclopentanones and amino acids like lysine, cysteine, serine and histidine which would contribute to a formation of active center in enzyme. The $\Delta \mathrm{N}$ value expresses the degree of polarization of charge in amino acid3-methylcyclopentanones complexes. The positive value of $\Delta \mathrm{N}$ indicates an electron will transfer from lower $\chi$ of amino acid to higher $\chi$ of 3-methylcyclopentanone. The $\Delta \mathrm{E}$ value should be equal to the magnitude of binding affinity with amino acid and 3-methylcyclopentanones. The big value of $\Delta \mathrm{N}$ or $\Delta \mathrm{E}$ means the easiness of the reaction with these amino acids and 3-methylcyclopentanones, and would suggest the strength of antibacterial activity of 3-methylcyclopentanones. The correlation coefficient of $\Delta \mathrm{N} v s \log (\mathrm{MIC})$ on B.subtilis was $-0.90 \sim-0.97$ and that of $-\Delta \mathrm{E}$ vs $\log (\mathrm{MIC})$ was -0.90

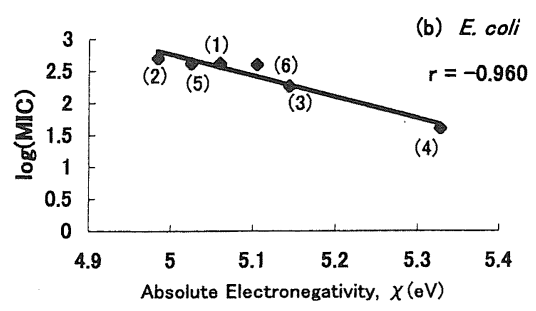

Fig. 3 Plot of Correlation between $\log (\mathrm{MIC})$ on (a) Bacillus subtilis and (b) Escherichia coli vs. Absolute Electronegativity $(\chi)$ of 3-Methylcyclopentanones.

(1) 3-Methyl-2-cyclopentenone (2) 2,3-Epoxy-3-methylcyclopentanone

(3) Methyl-5-methylene-2-cyclopentenone (4) 2,3-Epoxy-3-methyl-5-methylenecyclopentanone (5) 2-Chloro-3-methyl-2-cyclopentenone (6) 2-Chloro-3methyl-5-methylene-2-cyclopentenone 
$\sim-0.99$, respectively as shown in Fig. 4 and 5 .

The values of $\Delta \mathrm{N}$ and $\Delta \mathrm{E}$ also indicate the good indexes for predicting the antibacterial activity of 3-methylcyclopentanones.

The $\chi, \Delta \mathrm{N}$ and $\Delta \mathrm{E}$ values for binding affinities of methylenomycins with these amino acids were also investigated for the discussion of antibacterial activities of cyclopentanone antibiotics.

The compounds(11,12 and 13) are antibiotics known as 4-carboxy-methylenomycin B, methylenomycin $\mathrm{A}$ and sarkomycin, respectively and possess the big values of $\chi$ as well as $\Delta \mathrm{N}$ and $\Delta \mathrm{E}$ compared with other related compounds. To predict the relationship between structure and antibacterial activity, the values of $\chi$, for instance, on the compounds shown in Tables 2 and 3 were compared and the followings were found for the possession of big $\chi$.
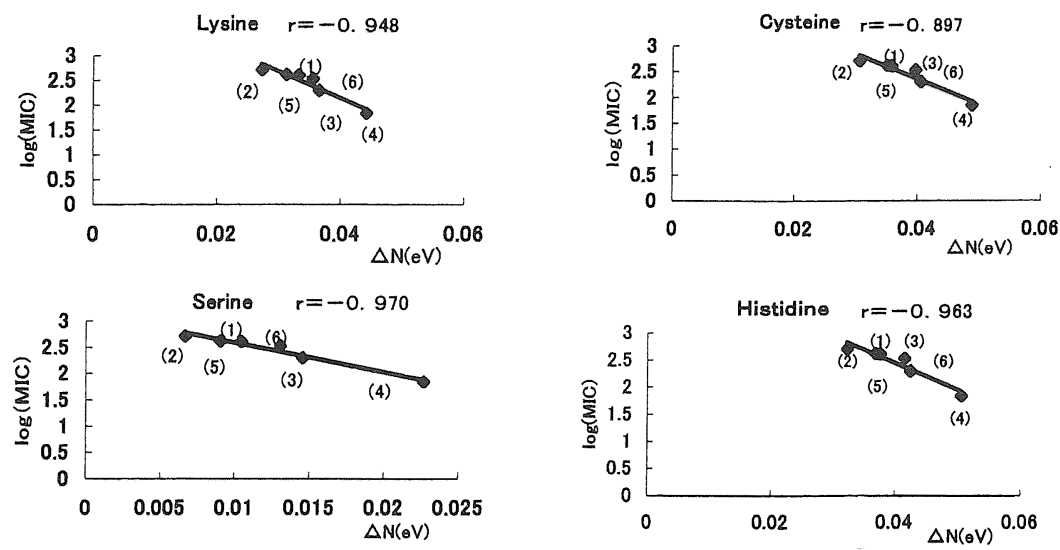

Fig. 4 Plot of Correlation between $\log (\mathrm{MIC})$ on Bacillus subtilis vs. Quantity of Electron Transfer $(\Delta \mathrm{N})$ from Amino acids to 3-Methylcyclopentanones.

(1) 3-Methyl-2-cyclopentenone (2) 2,3-Epoxy-3-methylcyclopentanone (3) 3-Methyl-5methylene-2-cyclopentenone (4) 2,3-Epoxy-3-methyl-5-methylenecyclopentanone (5) 2Chloro-3-methyl-2-cyclopentenone (6) 2-Chloro-3-methyl-5-methylene-2-cyclopentenone
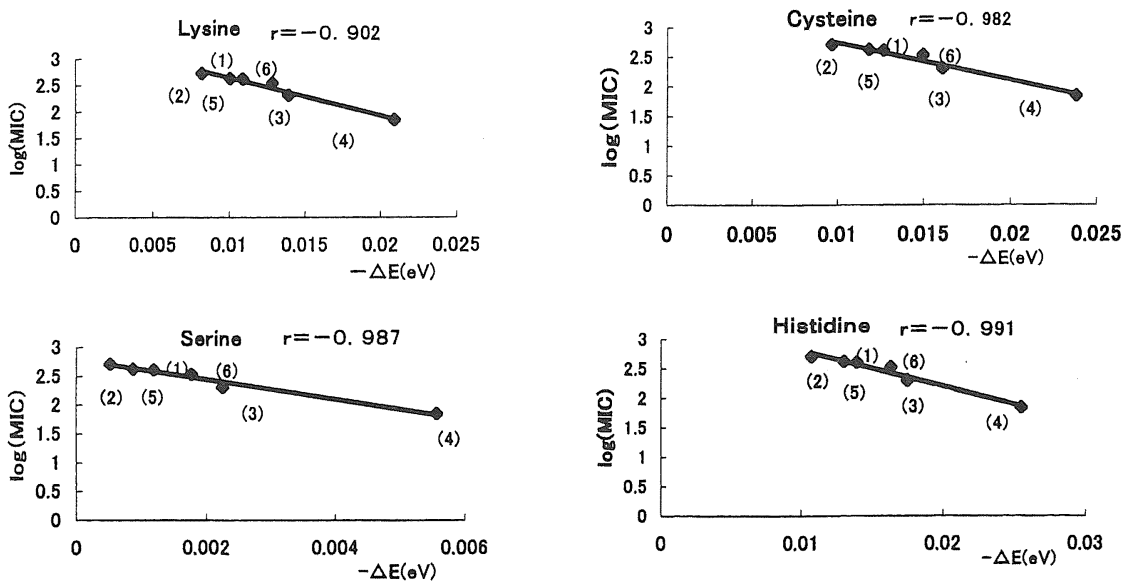

Fig. 5 Plot of Correlation between $\log (\mathrm{MIC})$ on Bacillus subtilis vs. Stabilization Energy $(\Delta \mathrm{E})$ for Binding Amino acids to 3-Methylcyclopentanones.

(1) 3-Methyl-2-cyclopentenone (2) 2,3-Epoxy -3-methylcyclopentanone (3) 3-Methyl-5methylene-2-cyclopentenone (4) 2,3-Epoxy-3-methyl-5-methylenecyclopentanone (5) 2Chloro-3-methyl-2-cyclopentenone (6) 2-Chloro-3-methyl-5-methylene-2-cyclopentenone 


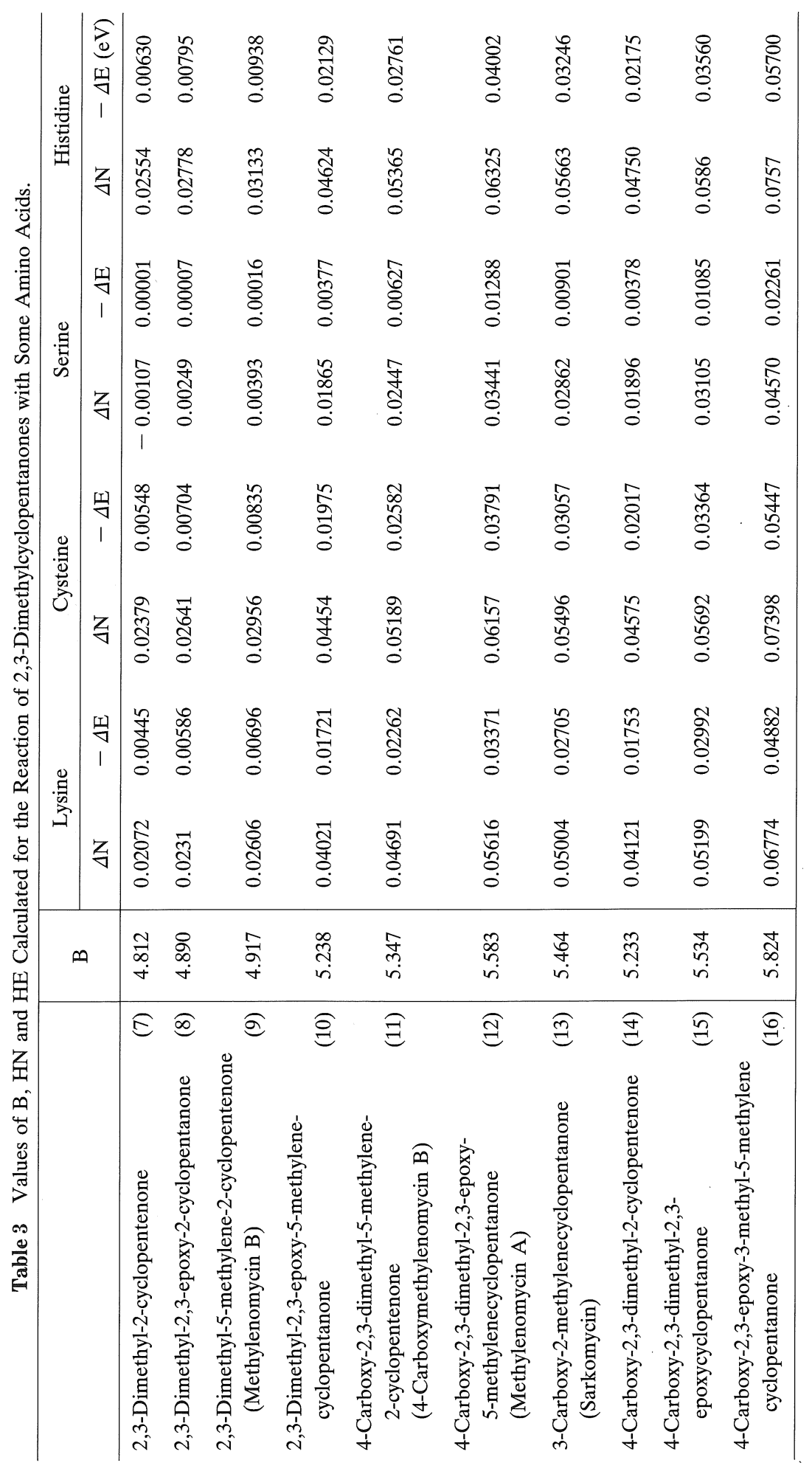


1. Methyl group at 2 position in cyclopentanone ring is not needed because the $\chi$ of 1 is bigger than that of 7 , similarly $\chi$ of $2>$ that of $8, \chi$ of $3>$ that of 9 and $\chi$ of $4>$ that of 10.

2. Carboxy group at 4 position affords big $\chi$ by comparison with 7 and 14 or 11 and 9 or 12 and $\mathbf{1 0 .}$

3. Coexistence of epoxy and exomethylene groups in the molecule contributes bigger $\chi$ than single possession of these as seen in the series of $4,3,2$ or $10,9,8$ or $12,15,11$.

Considering the above facts of 1,2 and 3 , the structure of 2-demethyl-methylenomycin A 16 possesses a bigger $\chi$ than that of methylenomycin $\mathrm{A}$ and is expected to possess a strong antibacterial activity.

The data comparison of $\chi, \Delta \mathrm{N}$ and $\Delta \mathrm{E}$ of methylenomycins with those of 4 , which showed the strongest antibacterial activity among the tested compounds, revealed that the values of $\chi$, $\Delta \mathrm{N}$ and $\Delta \mathrm{E}$ of 4 ranked between those of the compound(10 and 11), suggesting the 4 would expected to be a promissing cyclopentanone antibiotics.

The absolute electronegativity $(\chi)$ and quantity of electron transfer $(\Delta \mathrm{N})$ or stabilization energy $(\Delta \mathrm{E})$ which calculated from $\chi$ and $\eta$ of some amino acids and 3-methylcyclopentanones would suggest the good indexes for predicting the antibacterial activity of these related compounds.

\section{Acknowledgement}

The authors wish to thank Mr. H. Furukawa for synthesis of 3-methylcyclopentanones derivatives. (Received Nov. 15, 1999 ; Accepted Feb. 12, 2000)

\section{References}

1) (a) T. Haneishi, N. Kitahara, Y. Takiguchi, M. Arai, J. Antibio., XXVII(6) 386 (1974). (b) T. Haneishi, A. Terahara, M. Arai, T. Hata, C. Tamura, J. Antibio., XXVII(6) 393 (1974).

(c) T. Haneishi, A. Terahara, K. Hamano, M. Arai, J. Antibio., XXVII(6) 400 (1974).

2) U. Horneman, D. Hopwood, Tetrahedron Letters, 33, 2977 (1978).

3) K. Sakai, S. Amemiya, K. Inoue, K. Kojima, Tetrahedron Letters, 25, 2365 (1979).

4) (a) J. Jernow, W. Tautz, P. Rosen, J. F. Blount, J. Org. Chem., 44, 4210 (1979).

(b) J. Jernow, W. Tautz, P. Rosen, T. H. Williams, J. Org. Chem., 44, 4212 (1979).

5) R.M. Jr. Scarborough, B.H. Toden, A.B. Smith 1ll, J. Am. Chem. Soc., 102, 3904 (1980).

6) K. Tonari, K. Machiya, I. Ichimoto, H. Ueda, Agric. Biol. Chem., 45, 295 (1981).

7) (a) K. Toki, Agric. Biol. Chem., 31, 333 (1958).

(b) R.K. Hill, P.J. Jr. Foley, L.A. Gardella, J. Org. Chem., 2330 (1967).

(c) J.N. Marx, G. Minaskanian, Tetrahedron Letters, 43, 4175 (1979).

8) S. Kobayashi, K. Sameshima, Y.Ishii, K. Tanaka, Chem. Pharm. Bull., 43, 1780 (1995).

9) K. Watanabe, "Gendaiyuukikagaku" revised ed., Baifuukann Publication (1990) p.172.

10) C.R. Huchinson, J. Org. Chem., 36, 1854 (1974).

11) R.M. Achenson, Sir R. Robinson, J. Chem. Soc., 1127 (1952).

12) H.O. House, R.L. Wasson, J. Am. Chem. Soc., 79, 1488 (1957).

13) K. Tonari, Seikatu Eisei, 42, 187 (1998).

14) Computer calculation was performed by the configuration as follows. CPU : Intel Pentium III, BIOS RAM : $4 \mathrm{MB}$ and System RAM : $768 \mathrm{MB}$.

15) K. Nabeta, A. Ichihara, S. Sakamura, Agric. Biol. Chem., 39, 409 (1975).

16) C. Hansch, T. Fujita, J. Am. Chem. Soc., 86, 1616 (1964).

17) M.S. Tute, "Advan.Drug Res." 6, (1971) p.35, p.63.

18) T. Fujita, Nippon Nougeikagakukaisi, 41, (1967) R 41. 


\section{日本油化学会誌本号掲載 論文要旨}

\section{[総説]

$$
\begin{gathered}
\text { ステロールおよびトリテルペノイドの } \\
\text { 抗発がんプロモーター活性 }
\end{gathered}
$$

安川 憲*1 。秋久俊 博*2

*1 日本大学薬学部薬学科 (广 274-8555 千葉県船橋市習志野台 7-7-1)

*2 日本大学理工学部物質応用化学科 (广 101-8308 東京都千代田区神田駿河台 1-8)

21 世紀を目前とした今，がんの撲滅は人類に科せられた重要な課題である。我々は，これまでの食用植物や菌 類, さらには生薬における発がん抑制物質の探索に関する研究で, 種々のステロールやトリテルペンアルコール 並びにこれらの誘導体が，抗発がんプロモーターのin vivo一次スクリーニング試験法であるマウス耳款での TPA 誘発炎症に対して抑制効果を持つ事を見出してきた。本稿では，ステロールやトリテルペノイド類の TPA 誘発マウス耳款炎症，DMBA とTPAによるマウス皮膚二段階発がん実験，TPA 誘発 Epstein-Barr ウイルス活 性化，及び TPA 誘発 HeLa 細胞への燐の取り込みなど，種々の抗発がんプロモーター試験における抑制効果につ いて述べた。これらステロールやトリテルペノイドは食用植物，茸，及び生薬類の常成分であることから，毒性 は無いか極めて少ないと考えられる。従って，ステロールやトリテルペノイド類は発がん抑制物質として有望な 化合物群の一つとして期待される。

（連絡者：安川 憲・秋久俊博） Vol.49, No.6，571（2000）

\section{[報文 $]$}

$$
\begin{aligned}
& \text { メチレノマイシンに関連した } \\
& \text { 3-メチルシクロペンタノン類の抗菌性について }
\end{aligned}
$$

3-メチルシクロペンタノン類の抗菌性について, 分子軌道法の HOMO, LUMO から導かれる絶対的電気陰性 度 $(\chi)$ および絶対的ハードネス (

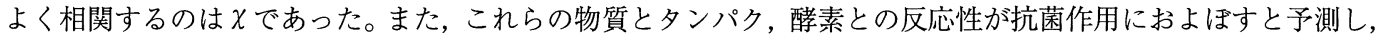
タンパク，酵素のシンプルなものとして数種のアミノ酸を選び，これらと 3-メチルシクロペンタノン類の反応性 指標と考えられる電荷移動量 $(\Delta \mathrm{N})$ および電荷移動親和力 $(\Delta \mathrm{E})$ を考察した。その結果，これらは 3-メチル シクロペンタノン類の MIC と強い相関があることが判明した。

五員環抗生物質として知られるメチレノマイシン関連物についても， $\chi ， \eta ， \Delta \mathrm{N}$ および $\Delta \mathrm{E}$ を比較した結果, 抗生物質として知られるものはこれらの絶対值がをいことが判明し, 今回得た 2,3-Epoxy-3-methyl-5-methylenecyclopentanone 4 も五員還抗生物質として期待できることが予測された。

（連絡者：登成 健之介） Vol.49, No.6, 583 (2000) 